\title{
TWO NEW SPECIES OF PLEUROTHALLIS (ORCHIDACEAE: PLEUROTHALLIDINAE) FROM COSTA RICA IN THE P. PHYLLOCARDIA GROUP
}

\author{
Franco Pupulin $^{1-3,5}$, Melissa Díaz-Morales ${ }^{1}$, Melania Fernández ${ }^{1,4} \&$ Jaime Aguilar $^{1}$ \\ ${ }^{1}$ Lankester Botanical Garden, University of Costa Rica. P.O. Box 302-7050 Cartago, Costa Rica \\ ${ }^{2}$ Harvard University Herbaria, 22 Divinity Avenue, Cambridge, Massachusetts 02138, U.S.A. \\ ${ }^{3}$ Marie Selby Botanical Gardens, 811 South Palm Avenue, Sarasota, Florida 34236, U.S.A. \\ ${ }^{4}$ Department of Plant \& Soil Science, Texas Tech University, Lubbock, Texas 79409, U.S.A. \\ ${ }^{5}$ Author for correspondence: franco.pupulin@ucr.ac.cr
}

\begin{abstract}
Two new species of Pleurothallis subsection Macrophyllae-Fasciculatae from Costa Rica are described and illustrated, and their relationships discussed. Pleurothallis pudica, from the central Pacific mountain region, is compared with P. phyllocardia, but it is easily recognized by the densely pubescenthirsute flowers. Pleurothallis luna-crescens, from the Caribbean slope of the Talamanca chain, is compared with $P$. radula and $P$. rectipetala, from which it is distinguished by the dark purple flowers and the distinctly longer, dentate petals, respectively. A key to the species of the group in Costa Rica and western Panama is presented.
\end{abstract}

Key words: flora of Costa Rica, new species, Pleurothallidinae, Pleurothallis phyllocardia group

Introduction. The species of Pleurothallis R.Br. close to Humboltia cordata Ruiz \& Pavón (1978) [= Pleurothallis cordata (Ruiz \& Pav.) Lindl.] represent one of the largest groups of taxa within the genus (Luer 2005). Phylogenetically, they are closely related to a group of species that includes the type of Pleurothallis, P. ruscifolia (Jacq.) R.Br. (Pridgeon et al. 2001, Pridgeon \& Chase 2001). The affinities among the species of the group were first recognized by John Lindley (1859), who created Pleurothallis sect. Macrophyllae-Fasciculatae for the species with tereteangulate stems, cordate leaves and fasciculate flowers; these were later considered a subsection within sect. Pleurothallis Luer (Luer 1988). The section has been treated at the generic rank by Szlachetko and Margońska (2001), who created Zosterophyllanthos, and by Luer (2005), who included the species of Pleurothallis sect. Macrophyllae-Fasciculatae into a broadened concept of Acronia C.Presl (1827). Neither of these alternative treatments has gained general consensus in botanical works (Pridgeon 2005, Karremans 2016).

Within the large assemblage of species that form subsect. Macrophyllae-Fasciculatae, accounting for more than 300 taxa (Luer 2005, Wilson et al. 2016), several different sets of species, each one with unique series of morphological and ecological characteristics, can be distinguished. Even excluding the group that Wilson and collaborators $(2011,2013)$ characterized as the "Mesoamerican clade" of Pleurothallis, consisting of fairly small plants and mostly non-resupinate flowers with deeply concave lips without basal glenions (Pupulin \& Zúñiga 2007), the subsection encompasses a large and heterogeneous assemblage of related taxa. These include the taxonomically difficult complex of species close to P. undulata Poepp. \& Endl., the first name applicable to a Pleurothallis species with small flowers resting on the leaf of plants that are mostly small in both habit and flower size (known as "frogs"), as well as much larger plants, some of which exhibit a characteristic temporal activity of the flowers (opening and closing the perianth during the day as an apparent response to environmental humidity), plus a number of taxa that simply do not fit any of the artificial groups, but are nonetheless closer to the species of sect. Macrophyllae-Fasciculatae than to any other group within Pleurothallis.

The present study discusses the taxonomy of two species of Pleurothallis belonging to the informal group characterized by large vegetative habit, i.e., mature plants with secondary stems (ramicauls) longer than $15 \mathrm{~cm}$, the inflorescence produced from an erect to suberect spathaceous bract, and flowers 
that do not exhibit temporal activity, remaining spread during the anthesis until they fade; hereafter referred to as the Pleurothallis phyllocardia group. Pleurothallis phyllocardia Rchb.f., originally proposed for a plant collected by Herman Wendland in Costa Rica (Reichenbach 1866), represents the oldest name applicable to a Pleurothallis species belonging to this assemblage of taxa.

The group is characterized by plants with softcoriaceous, elastic leaves, without a distinctly protruding mid-vein, matte on the upper surface, ovate to lanceolate, usually less than four times longer than broad (mostly $<4 \mathrm{~cm}$ wide), deeply cordate at the base when mature (immature leaves may be cuneate), and a spathaceous bract producing flowers that are erect to suberect, not prostrate (except in $P$. adventurae). The flowers are coriaceous, remaining open and mostly reflexing the sepals and petals after anthesis, with an erect dorsal sepal that is narrower than the synsepal. The lip is simple (rarely obscurely three-lobed), triangular-lanceolate, and thick, with a raised, rounded callus and a distinct glenion. Whilst the phylogenetic relationships among the different subsets of species artificially gathered in this study is not granted, they can nevertheless be easily distinguished as a group from other assemblages of taxa. Informally circumscribed, this group includes some 35 species, distributed from Costa Rica to Peru and Bolivia, with the highest diversity recorded in the northern Andes of Colombia and Ecuador (Luer 2005, Wilson et al. 2016).

Seven species are currently known from Costa Rica: $P$. adventurae Karremans \& Bogarín, P. compressa Luer, $P$. peculiaris Luer, $P$. phyllocardia, $P$. radula Luer, P. rectipetala Ames \& C.Schweinf. (Pupulin 2002, Luer 2003, Karremans \& Bogarín 2011), and $P$. silvae-pacis Karremans (Karremans \& Muñoz 2011), which could perhaps be a taxon of hybrid origin with species from a different group of Pleurothallis (Fig. 1). Here we describe two new species in this group.

\section{NEW SPECIES}

Pleurothallis pudica Pupulin, J.Aguilar \& M.Díaz, sp. nov.

TYPE: Costa Rica. San José: Pérez Zeledón, Paramo, Los Ángeles, along the road to San Gerardo de Dota, mountains to the north of Río División, on-line with the center Los Ángeles, 1700 m, 9'29'55” N $83^{\circ} 47^{\prime} 46^{\prime \prime} \mathrm{W}$, premontane rain forets, terrestrial on the edges of the road within the forest, 29 May 2014, A. P. Karremans 6249, G. Meza \& L. Oses (holotype, JBL; isotypes JBL). Figs. 2-3, 5.

Inter species generi Pleurothallidis spatha erecta, floribus dense tomentosis reclinatis super folium incumbentisque dignoscenda; a Pleurothallide phyllocardia Rchb.f. similis, sepalis et petalis pubescenti-hirsutis recedit.

Epiphytic, caespitose, erect herb up to $27 \mathrm{~cm}$ tall. Roots slender, flexuous, ca. $1 \mathrm{~mm}$ in diameter. Ramicauls terete, slender, $16.0-26.5 \mathrm{~cm}$ long, $0.15-0.20 \mathrm{~cm}$ in diameter, pale green, with two basal, tubular, obtuse sheaths of different size, the lower one loose $1.2-1.3 \mathrm{~cm}$ long, the upper tightly clasping 1.5-2.0 cm long, and a sub-basal, tubular, obtuse, tight sheath $3.8-4.5 \mathrm{~cm}$ long, the sheaths drypapyraceous, brown. Leaf borne at the apex of the ramicaul, reclinate toward the stem, thinly coriaceous, flexible, sessile, ovate, acute, shortly subacuminate, $5.3-8.2 \times 3.3-5.0 \mathrm{~cm}$, deeply cordate at the base, the basal lobes sometimes overlapping, green, matte. Inflorescence with a solitary flower, from an erect, rectangular-clavate, truncate, spathaceous bract 1.1$2.2 \mathrm{~cm}$ long, glumaceous, green, becoming brown, dry-papyraceous when mature. Pedicel terete, green, to $2.2 \mathrm{~cm}$ long. Ovary terete, curved-geniculate, 6-7 $\mathrm{mm}$ long. Flowers spreading, reclined toward the leaf, non-resupinate, the sepals purple-red, the petals and lip dark purple, pubescent-hirsute adaxially. Dorsal sepal erect, elliptic-lanceolate, acute, 9-10 $\times$ 4.5-5.0 mm, three-veined, pubescent-tomentose, more densely toward the apex, the trichomes white, translucent. Lateral sepals connate into an ovate, subobtuse synsepal, the margins slightly reflexed, pubescent-tomentose, distinctly shorter than the dorsal sepal, $7.0 \times 4.5 \mathrm{~mm}$, five-veined. Petals narrowly lanceolate-ligulate, subporrect, angulatedeflexed in the proximal third, acute, ciliate, $7.0 \times$ 1.8-2.0 mm, single-veined. Lip unguiculate, hinged to the column foot, strongly geniculate, broadly ovate-triangular, basally truncate with obtuse angles, broadly obtuse, minutely apiculate, the margins glandulose, the basal margins erect, $2.3 \times 3.0 \mathrm{~mm}$, 


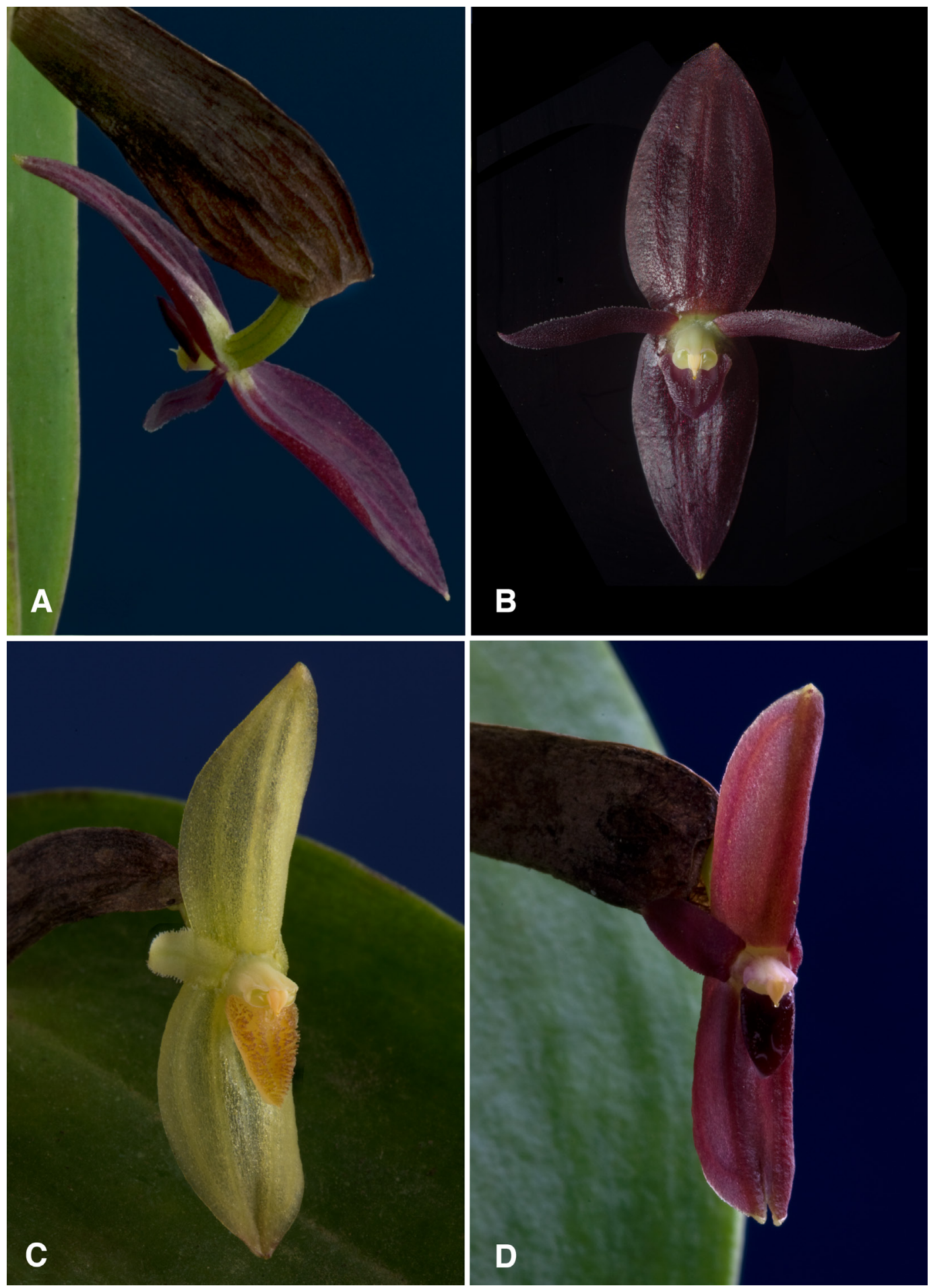

FIgURE 1. Representative flowers of the Pleurothalis phyllocardia group in Costa Rica. A-B, P. phyllocardia, in natural position (A) and detached, in frontal view (B) (JBL-01967, JBL). C, P. radula (Karremans 5162, JBL). D, P. rectipetala (Dressler 6565, JBL). Photographs by F. Pupulin. 


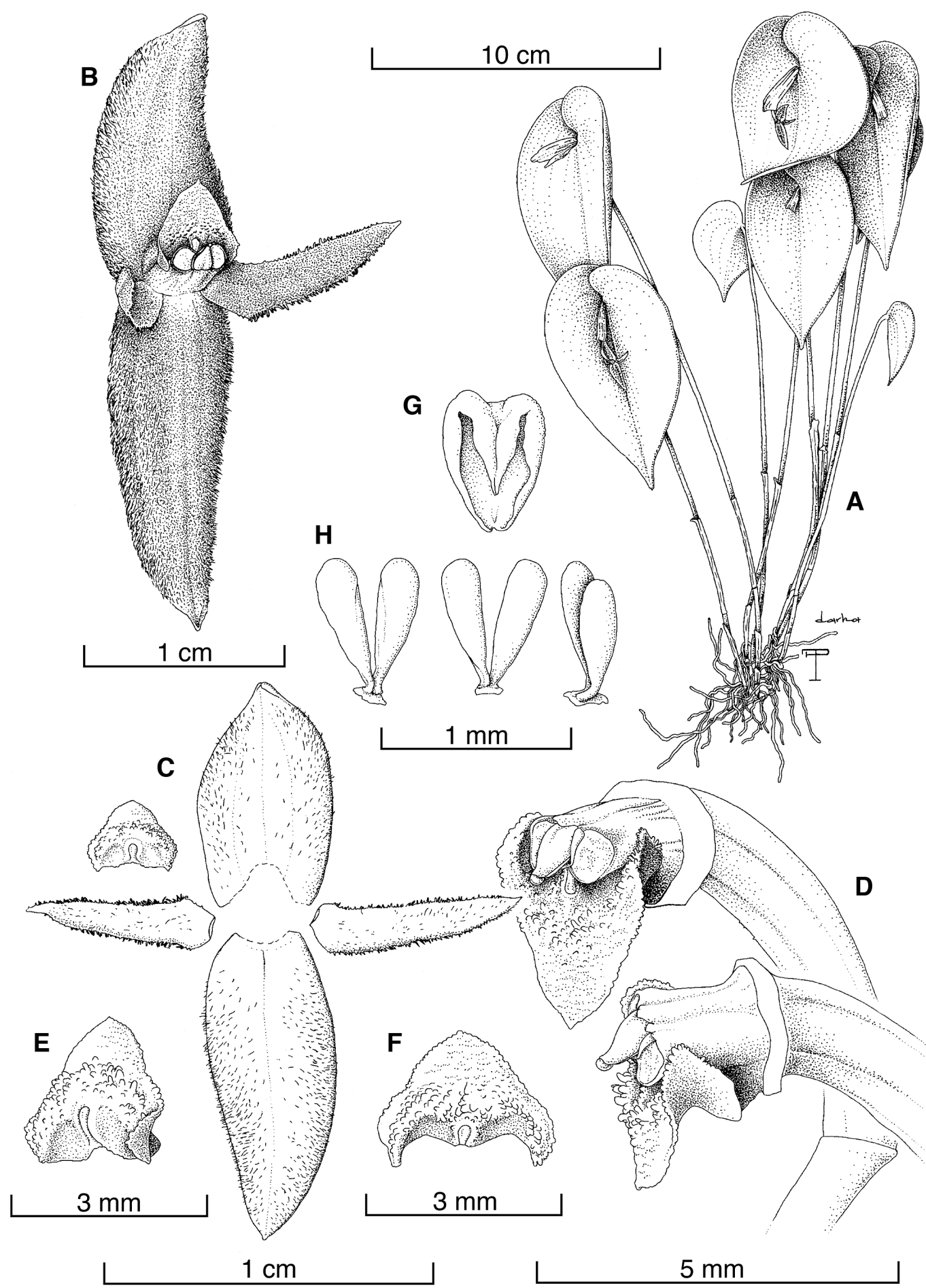

Figure 2. Pleurothallis pudica Pupulin, J.Aguilar \& M.Díaz. A, habit. B, flower. C, dissected perianth. D, column and lip, three quarters and lateral views. E, lip, three quarters view. F, lip, adaxial view. G, anther cap, H, pollinarium, dorsal, ventral, and lateral views. Drawn by F. Pupulin and D. Solano Ulate from the holotype. 


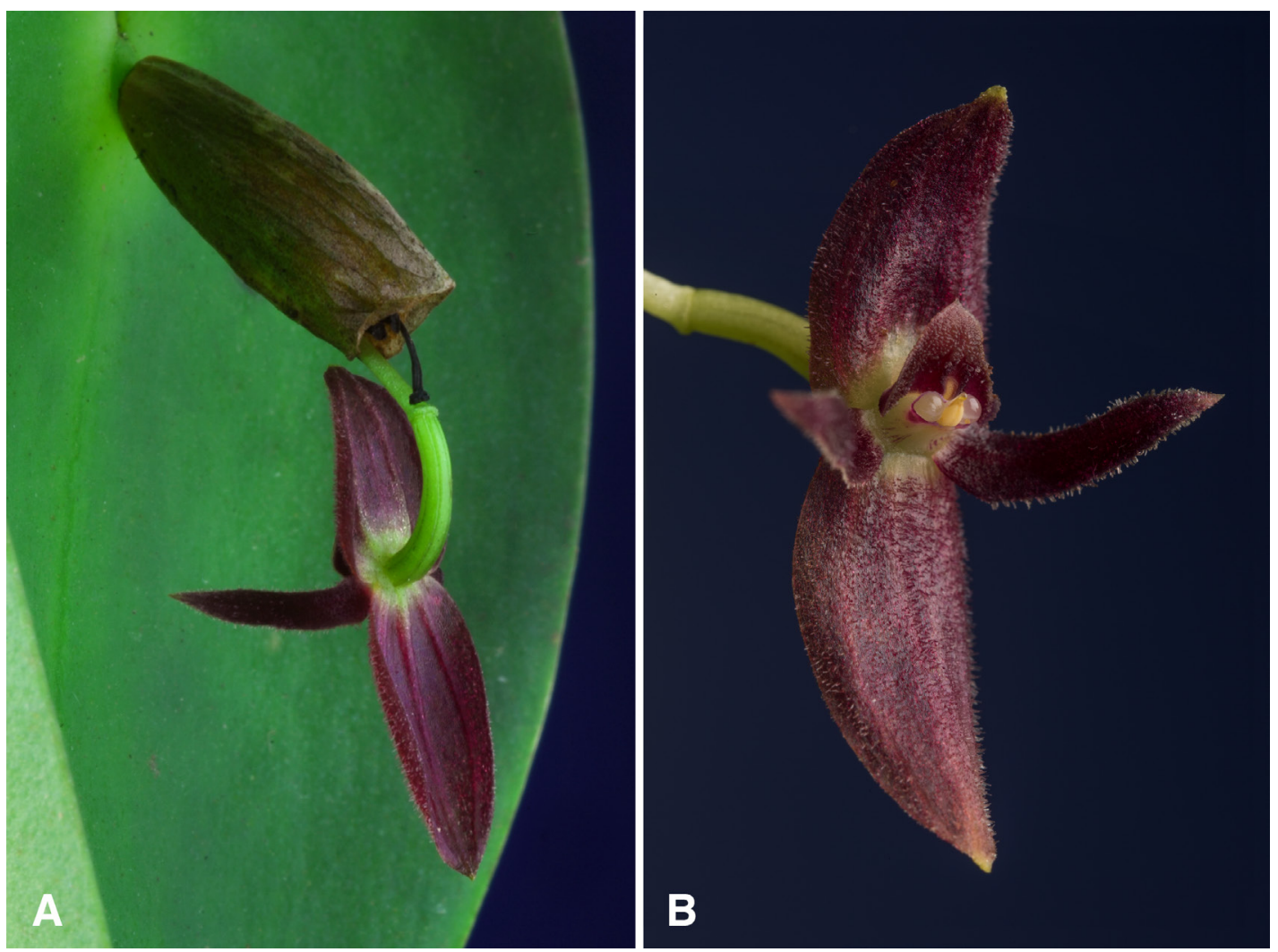

Figure 3. Pleurothallis pudica. A, flower in natural position, facing the leaf. B, detached flower from the front. Photographs by F. Pupulin.

covered with coarse papillae at the base; glenion raised on a thick callus on the disk ca. $0.4 \mathrm{~mm}$ long. Column short, stout, transversely subrectangular, dorsiventrally complanate, ca. $3.5 \times 3.0 \mathrm{~mm}$, the anther apical, incumbent, the stigma apical, bilobed. Anther cap cucullate, ovate, subcordate, truncate, two-celled, ca. $0.8 \times 0.6 \mathrm{~mm}$. Pollinia two, narrowly ovate-pyriform, $0.7 \mathrm{~mm}$ long, attached to an elliptic viscidium. Fruit not seen.

Distribution: Known only from the Pacific slopes of the Talamanca mountain chain in central Costa Rica (Fig. 4).

Habitat AND ECOlOGY: The only known specimen was found growing among mosses on a road cut within a montane forest at about $1700 \mathrm{~m}$ elevation.

Etymology: From the Latin pudicus, chaste, modest, shamefaced, in reference to the habit of turning the face of the flower toward the leaf, hiding it from the view of the observer.

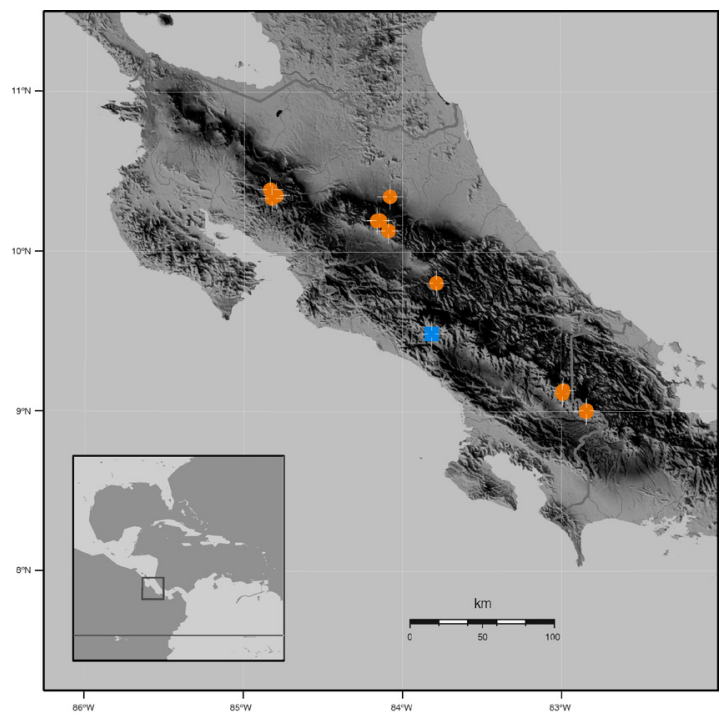

Figure 4. Map of Costa Rica, showing the known distribution of Pleurothallis pudica (blue square) and P. phyllocardia (orange dots). 
Pleurothallis pudica is easily recognized among the species of the group by the pubescent-hirsute flowers facing down and reclinate over the leaf. The reclination of the perianth, which leaves a quite small space between the flower and the surface of the leaf for allowing the pollinator to explore the flower, is a very uncommon feature in the Pleurothallidinae in general. Apart from the Costa Rican P. phyllocardia, this character has been recorded in only two other species of Pleurothallis subsect. MacrophyllaeFasciculatae: P. valladolidensis Luer, from Ecuador, and $P$. alopex Luer, from the lowlands of Paraguay. Pleurothallis pudica is the fourth species in the group showing the same arrangement of the flower, which likely corresponds to a still unknown pollination syndrome that appeared independently in the mountains of Central American, in the Andes, and in the forest of eastern South America.

Besides the characteristic indumentum of the abaxial surface of the sepals, the flowers of $P$. pudica can be distinguished from those of P. phyllocardia by the reflexed margins of the sepals, and the angulatedeflexed shape of the petals (Fig. 5).
Pleurothallis luna-crescens Pupulin, J.Aguilar \& Mel. Fernández, sp. nov.

TYPE: Costa Rica. Cartago: Turrialba, Tayutic, Grano de Oro. On the road to the premontane forest, next to the road between Grano de Oro and Llanos del Quetzal, $2 \mathrm{Km}$ after crossing a river with a broken bridge. $9^{\circ} 48^{\prime} 23^{\prime \prime} \mathrm{N} 83^{\circ} 26^{\prime} 53^{\prime \prime} \mathrm{W}, 1000-1200 \mathrm{~m}, 30$ July 2005 , A. P. Karremans 881 \& P. Ferreira (holotype, CR; isotypes, JBL). Figs. 6-7A.

Inter species generi Pleurothallidis spatha erecta, sepalis petalisque valide reflexis, sepalo postico synsepaloque fortiter incurvatis formam lunae crescentis flore conferens dignoscenda; Pleurothallide radula Luer et Pleurothallide rectipetala Ames et C.Schweinf. similis, sed floribus atrovinaceis (vs luteos) et petalis multo longioribus marginibus distincte dentatis (vs. minute denticulatos) recedit.

Epiphytic, caespitose, erect herb up to $26 \mathrm{~cm}$ tall. Roots slender, flexuous, ca. $1 \mathrm{~mm}$ in diameter. Ramicauls terete, slender, $7.5-25.0 \mathrm{~cm}$ long, $0.30-0.35$ $\mathrm{cm}$ in diameter, pale green, with a basal, tubular, truncate sheath, 2.5-4.2 cm long, and a sub-basal, tubular,

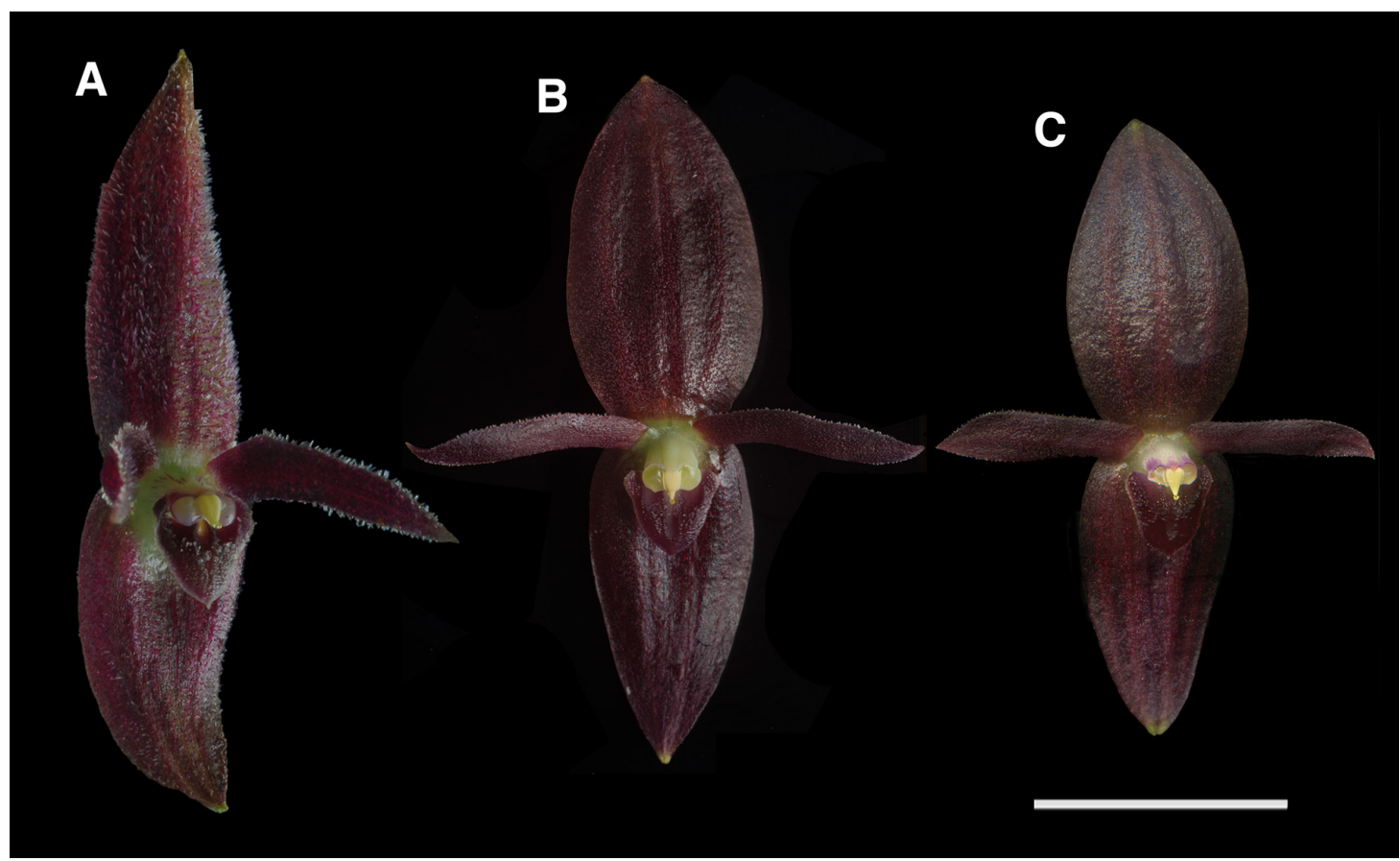

Figure 5. Comparison of the flowers of Pleurothallis pudica (A) and P. phyllocardia (B-C). A, Karremans 6249. B, JBL16797. C, Fernández 936. All the vouchers at JBL. Photographs by F. Pupulin. 

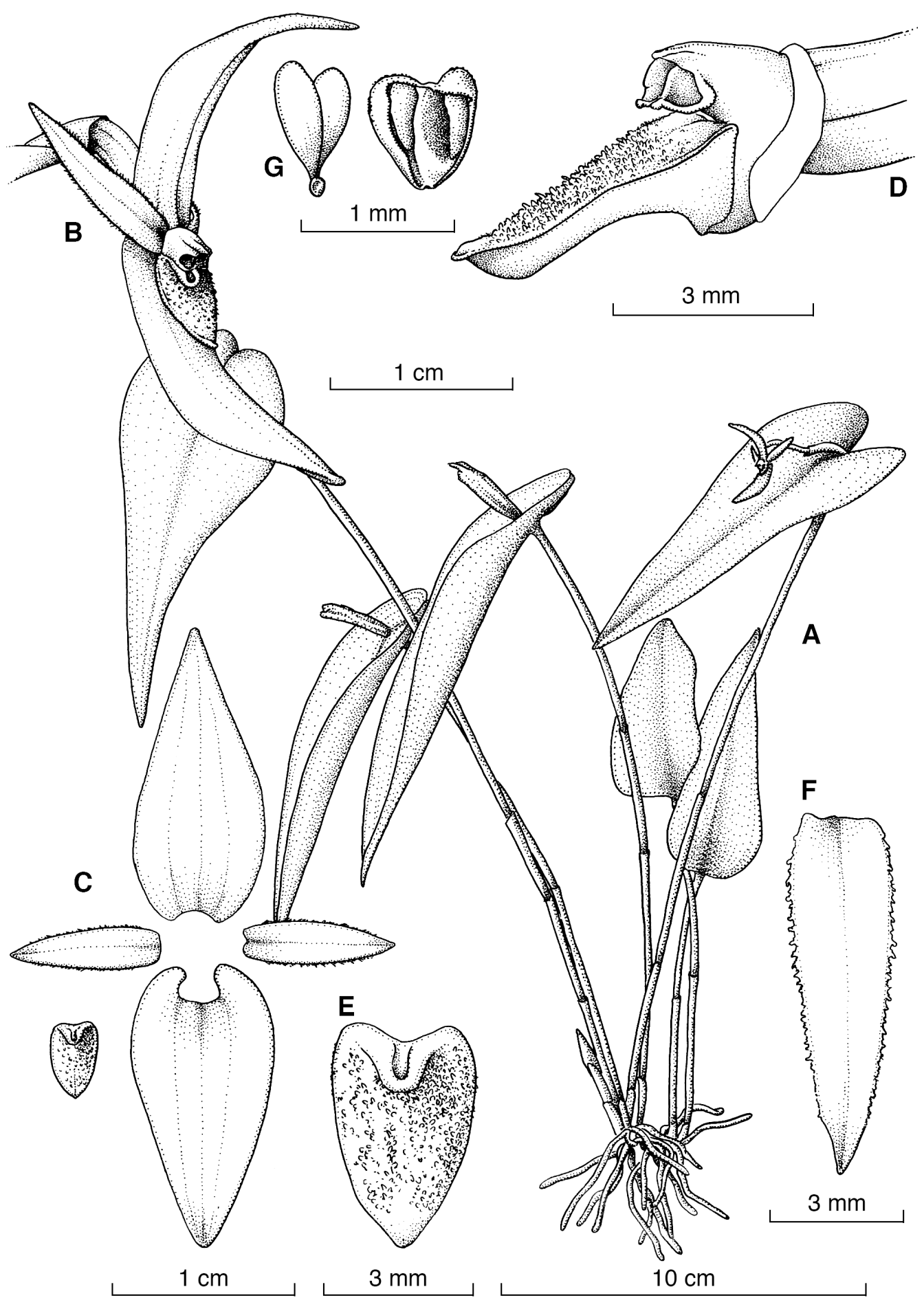

Figure 6. Pleurothallis luna-crescens Pupulin, J.Aguilar \& Mel.Fernández. A, habit. B, flower. C, dissected perianth. D, column and lip, lateral view. E, lip, adaxial view. F, petal. G, pollinarium and anther cap. Drawn by F. Pupulin and D. Solano Ulate from the holotype. 

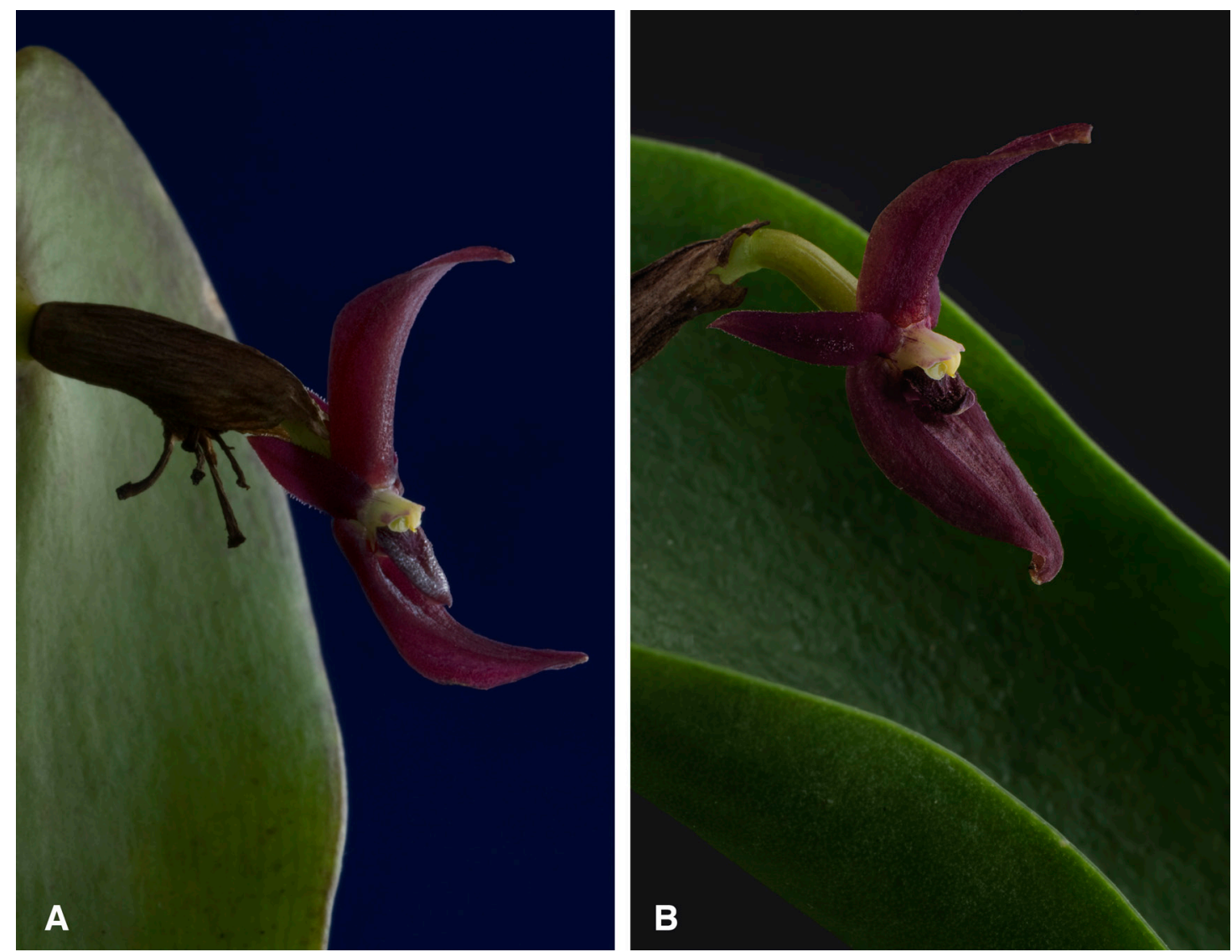

Figure 7. Flowers of Pleurothallis luna-crescens. A, Karremans 881. B, Fernández 461. Photographs by F. Pupulin.

obtuse, tight sheath $2.3-5.2 \mathrm{~cm}$ long, dry-papyraceous, brown when mature. Leaf borne erect at the apex of the ramicaul, becoming subpendent with age, thinly coriaceous, flexible, sessile, lanceolate, acute, shortly subacuminate, $6.5-12.5 \times 3.0-5.5 \mathrm{~cm}$, deeply cordate at the base, green, matte. Inflorescence a solitary flower, from an erect, rectangular-subclavate, truncate, spathaceous bract $2.2-2.6 \mathrm{~cm}$ long, glumaceous, green, becoming brown, dry-papyraceous when mature. Pedicel terete, green, to $2.2 \mathrm{~cm}$ long. Ovary terete, subclavate, 6-7 mm long. Flowers spreading, the sepals and petals purple-red, the lip dark purple. Dorsal sepal reflexed, incurved, lanceolate, acute, $15.0-16.5 \times 6.5-7.0 \mathrm{~mm}$, three-veined. Lateral sepals connate into an ovate, obtuse synsepal, the margins slightly reflexed, incurved, $14.8-15.3 \times 8.0-8.5 \mathrm{~mm}$, five-veined. Petals narrowly ovate, acute, dentate, 8.7-9.0 $\times 2.8-3.0 \mathrm{~mm}$, single-veined. Lip unguiculate, hinged to the column foot, ovate, basally truncate with obtuse angles, obtuse, minutely apiculate, 4.0-4.5 $\times 2.2-2.8 \mathrm{~mm}$, minutely papillate; glenion raised on a thick callus on the disk ca. $0.6 \mathrm{~mm}$ long. Column short, stout, transversely subrectangular, dorsiventrally complanate, ca. $2.0 \times 1.3 \mathrm{~mm}$, the anther apical, incumbent, the stigma apical, bilobed. Anther cap cucullate, ovate, subcordate, truncate, two-celled, ca. $0.9 \times 0.7 \mathrm{~mm}$. Pollinia two, narrowly ovate-pyriform, $0.8 \mathrm{~mm}$ long, attached to an elliptic viscidium. Fruit not seen.

Other specimens studied: Costa Rica. Cartago: Orosi, Tapantí, Parque Nacional Tapantí, sendero Árboles Caídos, $1280 \mathrm{~m}$, epiphytc on low trunks in primary wet submontane forest, 6 Feb. 2000, F. Pupulin 1981 (USJ); Turrialba, La Suiza, Llanos del Quetzal, ca. $1 \mathrm{~km}$ on the road behind the School of Kabébata (Alto Quetzal), epiphytic in primary and sexondary vegetation, premontane wet forest, 
946'43.6”"N 8324'41.6”'W, 1450 m, 17 Jun. 2011, A. P. Karremans 4262, M. Fernández \& D. Bogarín (JBL); Turrialba, La Suiza, Llanos del Quetzal, road to Chirripó Abajo, 9०46'55.4” N 83²4'21.0”'W, $1411 \mathrm{~m}$, epiphytic in secondary vegetation around the road, premontane wet forest, 17 Jun. 2011, M. Fernández 461, A. Karremans \& D. Bogarín (JBL) (Fig. 7B); Cartago, San Francisco, Navarro, Muñeco, Fincas Loma Verde y Jilguero, road to Alto Belén, between Río Sombrero and Quebrada Patarrá, 9 $466^{\prime} 50.3$ ”N 8354'21.1”O, 1430-1620 $\mathrm{m}$, premontane reain forest, secondary woods and margins of the road, 23 May 2007, J. D. Züñiga 178, D. Bogarín, M. Bonilla, R. Gómez, R. L. Dressler \& R. Trejos (JBL); Cartago: Turrialba, Tayutic, Platanillo. Hillside of the Platanillo River, 9०49'11'N 8333'37'”, 700-900m, 30 April 2005, A. Karremans 801 (JBL); [Cartago: Turrialba] Alto Pacuare, epiphyte, purple flowers, alt. $100 \mathrm{~m}, 21$ July 1978, R. A. Ocampo S. 2363 (CR).

ETyMology: From the Latin luna crescens, crescent moon, in reference to the characteristic shape of the flower seen in profile, due to the strongly reflexed-incurved sepals.

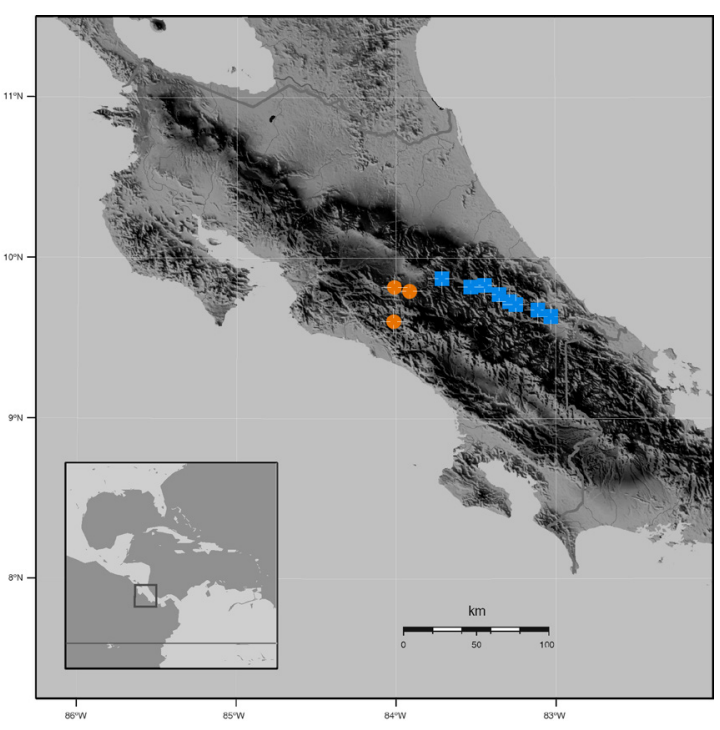

FIgURE 8. Map of Costa Rica, showing the known distribution of Pleurothallis luna-crescens (blue square) and $P$. radula (orange dots).

Distribution: Known only from the Caribbean slopes of the northern Talamanca chain, in central Costa Rica (Fig. 8).

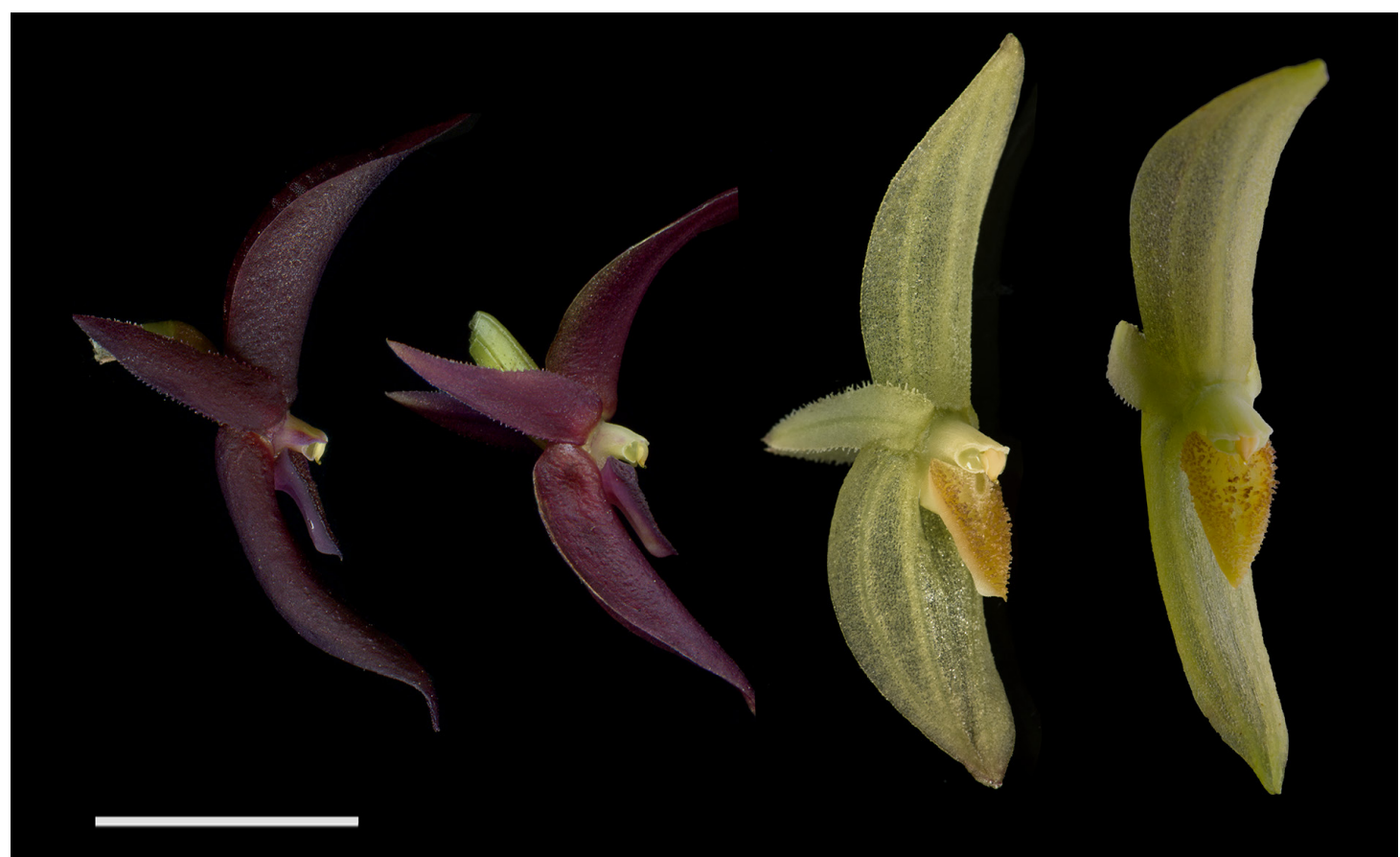

Figure 9. Comparison of the flowers of Pleurothallis luna-crescens (A-B) and P. radula (C-D). A, Karremans 881. B, Zúñiga 178. C, Karremans 5162. D, Pupulin 7797. All the vouchers at JBL. Photographs by F. Pupulin. 
Habitat And eCOlogy: Epiphytic on branches in the partial shade of the lower canopy, in lower montane and premontane rain to wet forest at $700-1600 \mathrm{~m}$ elevation.

Among the species of Pleurothallis with cordate, narrow, reflexed leaves and erect spathes, $P$. lunacrescens is most similar to $P$. radula, but the latter has flowers invariably concolorous yellow (Fig. 9), and the lip is covered by an indumentum formed by densely packed, shortly tuberculate-dentate, irregular projections, which are absent in P. luna-crescens (Fig.
10). It is also similar to $P$. rectipetala, but the crescentshaped flowers (vs. straight), and the longer petals ( $>3$ times longer than broad) with strongly dentate margins ( $v s$. minutely denticulate) of the new taxon distinguish the two species. Pleurothallis rectipetala has been compared (Luer 2005) with the Panamanian P. scitula Luer, but the latter species has ovate leaves and pubescent flowers, with the sepals almost as long as the sepals, while both the protologue and the type of the Costa Rican P. rectipetala show a glabrous flower with shorter petals (approximately half long as the sepals).

\section{Key to the species of the Pleurothallis phyllocardia group in Costa Rica and western Panama}

1. Flowers non resupinate

2. Ramicaul ancipitous; synsepal broader than the dorsal sepal; petals linear-lingulate, glabrous

2a. Ramicaul terete; synsepal narrower than the dorsal sepal; petals obovate, pubescent $\quad$ P. peculiaris 1a. Flowers resupinate

3. Spathe prostrate; adaxial surface of the flowers completely covered with short, stiff, pointed tubercles

3a. Spathe erect or suberect, not prostrate; flowers glabrous or covered with soft, white hairs within 4

4. Flowers reclinate, facing the leaf

5. Flowers glabrous

P. phyllocardia

5a. Flowers with the inner surface pubescent-tomentose

P. pudica

4a. Flowers erect, not facing the leaf

6. Sepals concave

P. silvae-pacis

6a. Sepals reflexed

7. Flowers concolorous yellow; the lip with high, dense, shortly tuberculate-dentate, irregular projections

7a. Flowers dark purple, sometimes with subhyalinous dorsal sepal; lip glabrous or with low, rounded papillae

8. Flowers moon-shaped in profile

P. luna-crescens

8a. Flowers straight in profile

9. Leaves ovate; flowers pubescent, yellow marked with purple;petals $>3$ times longer than broad (only recorded from Panama) P scitula

9a. Leaves narrowly lanceolate; flowers glabrous, concolorous dark purple; petals $<3$ times longer than broad

P. rectipetala

Acknowledgments. The scientific services of the Costa Rican Ministry of Environment and Energy (MINAE) and National System of Conservation Areas (SINAC) kindly issued the collecting permits under which wild specimens treated in this paper were collected. We are indebted to Diego Bogarín and Adam Karremans for the continuous and prolific discussion on the taxonomy and systematic of the Pleurothallidinae, and to Darha Solano Ulate for finely inking the illustrations. We acknowledge three anonymous reviewers, whose suggestions and discussion greatly improved the manuscript. This research was enabled by the Project 814-A0-052, "Flora Costaricensis, Orchidaceae, subtribe Pleurothallidinae", supported by the VicePresidency of Research, Universidad de Costa Rica. 

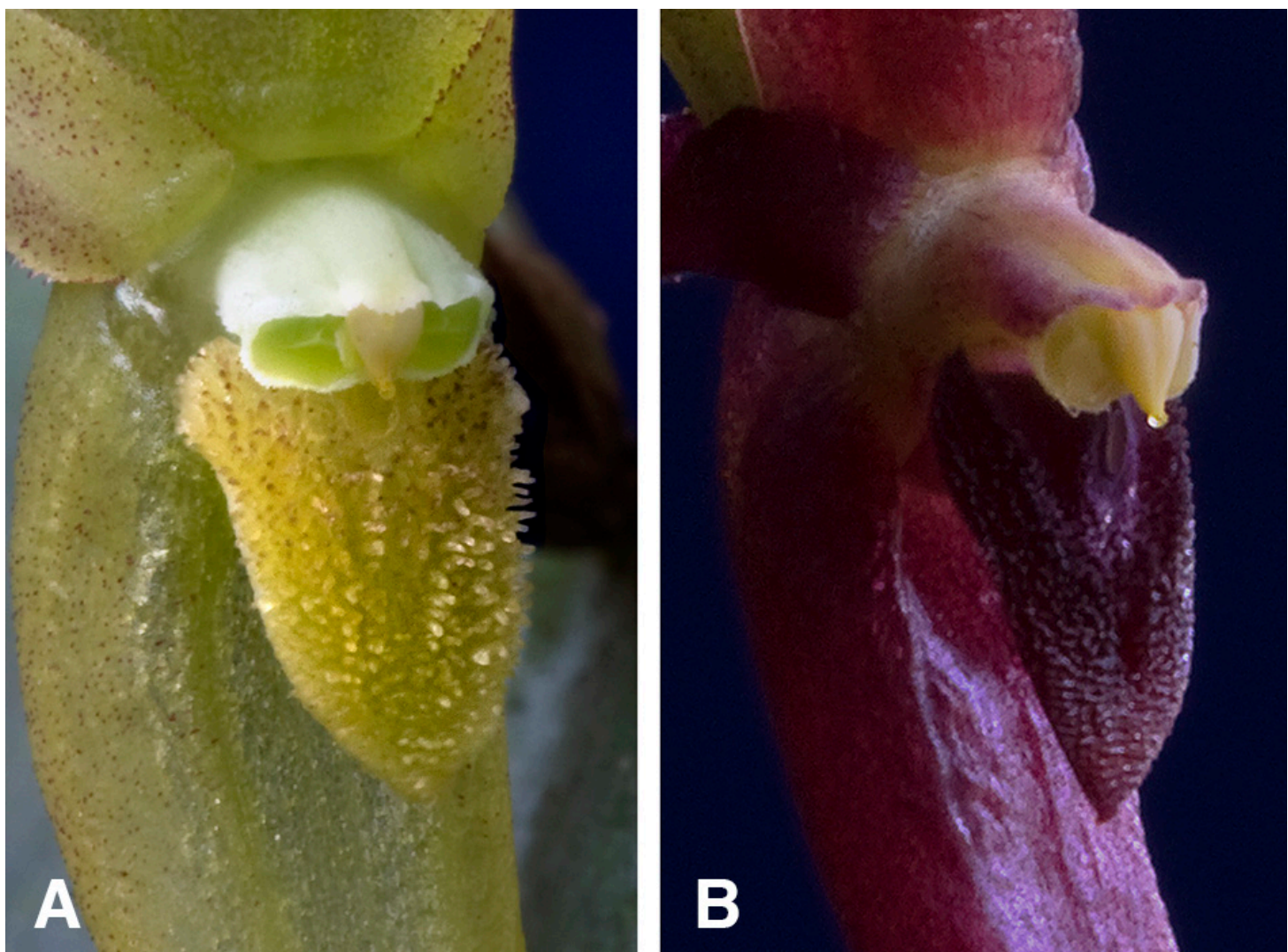

Figure 10. Close-up views of the labella of Pleurothallis radula (A, Pupulin 7796) and P. luna-crescens (B, Karremans 881). All the vouchers at JBL. Photographs by F. Pupulin.

\section{LITERATURE CITED}

Karremans, A. P. (2016). Genera Pleurothallidinarum: an updated phylogenetic overview of Pleurothallidinae. Lankesteriana, 16(2), 219-241.

Karremans, A. P. \& Bogarín, D. (2011). Pleurothallis adventurae (Orchidaceae: Pleurothallidinae), eine neue Art aus einer unerforschten Region in Costa Rica. OrchideenJournal, 18(3), 111-114.

Karremans, A. P. \& Muñoz, M. (2011). Pleurothallis silvaepacis, a new species. Orchid Review, 121,155-159.

Lindley, J. (1859). Folia Orchidacea. An enumeration of the known species of orchids. Pleurothallis 9-12. Published for the author, by J. Matthews, London.

Luer, C. A. (1988). A revision of some sections of subgenus Pleurothallis. Lindleyana, 3(3), 133-149.

Luer, C. A. (2003). Pleurothallis. In: B.E. Hammel, M.H, Grayum, C. Herrera \& N. Zamora (eds.), Manual de Plantas de Costa Rica. Volumen III: Monocotiledóneas (Orchidaceae-Zingiberaceae) (pp. 386-452). Monographs in Systematic Botany from the Missouri Botanical Garden, 93.
Luer C. A. (2005). Icones Pleurothallidinarum XXVII. Dryadella and Acronia sect. MacrophyllaceaeFasciculatae. Monographs in Systematic Botany from the Missouri Botanical Garden, 103, 1-311.

Presl, C. B. (1827). Reliquiae Haenkeanae, seu Descriptiones et icones plantarum, quas in America Meridionali et Boreali, in insulis Philippinis et Marianis collegit Thaddaeus Haenke. Fasc. 2, pp. 85-148. Pragae: Apud J.G. Calve.

Pridgeon, A. M. (2005). Pleurothallis. In: A. M. Pridgeon, P. Cribb, M. W. Chase \& F. N. Rasmussen (eds.), Genera Orchidacearum: Volume 4: Epidendroideae (Part 1) (pp. 385-390). Oxford: Oxford University Press.

Pridgeon, A. M. \& Chase, M. W. (2001). A phylogenetic reclassification of the Pleurothallidinae (Orchidaceae). Lindleyana, 16, 2365-2371.

Pridgeon, A. M., Solano, R. \& Chase, M. W. (2001). Phylogenetic relationships in subtribe Pleurothallidinae (Orchidaceae): combined evidence from nuclear and plastid DNA sequences. American Journal of Botany, 
88, 2286-2308.

Pupulin F. (2002). Catálogo revisado y actualizado de las Orchidaceae de Costa Rica. Lankesteriana, 4, 1-88.

Pupulin, F \& Zúñiga, J. D. (2007). The upside-down Pleurothallis of Mesoamerica with a new species from Costa Rica. Orchids (The Bulletin of the American Orchid Society), 76(9), 690-695.

Reichenbach, H. G. (1866). Beiträge zu einer Orchideenkunde Central-Amerika's. Hamburg: Druck von T. G. Meissner.

Ruiz, H. \& Pavón, J. (1798). Systema vegetabilium florae peruvianae et chiliensis. Madrid: Gabrielis de Sancha.

Szlachetko, D. L. \& Margonska, B. H. (2001). Genera et species orchidalium. Polish Botanical Journal, 46(2), 113-121.

Wilson, M., Belle, C., Dang, A., Hannan, P., Kenyon, C., Low, H., Stayton, T. \& Woolley, M. (2011). A phylogenetic analysis of the genus Pleurothallis, with emphasis on Pleurothallis subsection MacrophyllaeFasciculatae, using nuclear ITS and chloroplast DNA sequencing. Lankesteriana, 11(3), 369.

Wilson, M., Belle, C., Dang, A., Hannan, P., Kellogg, L., Kenyon, C., Low, H., Mochizuki, A., Nguyen, A., Sheade, N., Shan, L., Shum, A., Stayton, T., Volz, C., Vosburgh, B., Wellman, H. \& Woolley, M. A. (2013). Preliminary phylogenetic analysis of Pleurothallis sensu lato based upon nuclear and plastid sequences. Lankesteriana, 13(1-2), 139.

Wilson, M., Baquero, L., Dupree, K., Jiménez, M. M., LeBlanc, C., Merino, G. Portilla, J., Salas Guerrero, M., Tobar Suárez, F. \& Werner, J. D. (2016). Three new species of Pleurothallis (Orchidaceae: Pleurothallidinae) in subsection Macrophyllae-Fasciculatae from northern South America. Lankesteriana, 16(3), 349-366. 